\title{
A Short Review on Electrosurgery in Dentistry
}

\author{
Krishna Madhu Kumaran Pillai Sreekaladevi ${ }^{1 *}$, Hridya Jayaprakash ${ }^{2}$, \\ Divya Sudhakar ${ }^{3}$, Aishwarya Dham ${ }^{4}$, Radhika Srikhakollu ${ }^{5}$ and \\ Shalini Panchacharam ${ }^{6}$ \\ ${ }^{1}$ Ex-Postgraduate, Department of Oral Medicine and Maxillofacial Radiology, KVG \\ Dental College and Hospital, Sulliya, India \\ ${ }^{2}$ Periodontist, Clove Dental, Sholinganallur, Chennai, Tamil Nadu, India \\ ${ }^{3}$ General Dentist, Masthan Dental Hospital, Chennai, Tamil Nadu, India \\ ${ }^{4}$ Periodontist, Ranchi, Jharkhand, India \\ ${ }^{5}$ General Dentist, Rhode Island, USA \\ ${ }^{6}$ General Dentist, Arakkonam, Tamil Nadu, India \\ *Corresponding Author: Krishna Madhu Kumaran Pillai Sreekaladevi, \\ Ex-Postgraduate, Department of Oral Medicine and Maxillofacial Radiology, KVG \\ Dental College and Hospital, Sulliya, India.
}

DOI: $10.31080 /$ ASDS.2022.06.1315
Received: January 21, 2022

Published: February 10, 2022

(C) All rights are reserved by Krishna Madhu

Kumaran Pillai Sreekaladevi., et al.

\begin{abstract}
In electrosurgery, electric current is precisely applied to the soft tissues by electrodes to obtain cutting of tissues. The electric current generated in electrosurgery is also used for incision, excision, hemostasis and coagulation of tissues. The mode of the use of this electric current could be changed for cutting or coagulating soft tissues. This article briefly explains the literature review of ES and its clinical application in dentistry.
\end{abstract}

Keywords: Electrosurgery; Excision; Coagulation

\section{Introduction}

Electrosurgery (ES) has been used among dental professionals for more than five decades now. During the last three decades, a substantial increase in need for minimally invasive procedures prompted greater use of ES. ES is defined as the flow of high frequency electric current into tissues in a controllable manner to obtain desired effect on tissues [1]. The mode or frequency of electric current used can be changed according to the use needed.i.e., cutting or coagulation of tissues. The focus of this article is to provide a superficial view on use of electrosurgery in dental field.

\section{Electrosurgical system $[2,3]$}

Electrosurgical unit

Basically, there are two types of ES, monopolar and bipolar units. In monopolar units, Electric current flow starts with the ES unit, asses on to the oral tissue, followed by its flow to an another plate which is placed on patient's back. When the surgical electrode touches oral soft tissues, heat is generated and controlled cutting of tissues is achieved. Bipolar units have two different electrodes on the tip. There is flow of current from one electrode to another in bipolar units. Hence the cut is made broader when bipolar electrodes are used. An indifferent plate is not needed in bipolar ES units.

\section{Electric frequency}

ES units works at a particular fixed frequency predetermined by the manufacturer. It varies for each model. The frequency of current flow is more in the monopolar ES units when compared to the bipolar ES units.

\section{Electrodes}

In the monopolar system, a high-frequency current is passed onto the active electrode. The circuit is continued to the patient and 
the dispersive electrode. The flow of current passing through the active electrode is much smaller when compared to the dispersive electrode. Patient is also included in monopolar ES units.

In bipolar systems, the size and shape of the active electrode is equal to the dispersive electrode. Both the electrodes are attached to the same handpiece or probe.

\section{Indications [4]}

- Clinical crown lengthening

- Gingivectomies and gingivoplasties

- Removal of operculum

- Frenectomies

- I \& D of abscesses

- Hemostasis

- Biopsy

- Periodontal pocket treatment

\section{Contraindications}

- $\quad$ Patients with pacemaker

- In areas close to the bone.

Guidelines to use Electrosurgical unit [5]

- Higher frequency current is used for incision.

- Smallest possible electrode should be used always.

- $\quad$ Minimum rate of incision is $7 \mathrm{~mm} / \mathrm{s}$.

- Cooling period of 8 seconds should be given between two successive incisions.

- $\quad$ Should not contact cementum or where tissue attachment is desired.

- Minimal recession should be anticipated when used along the gingival crevice.

- Excessive contact on alveolar bone would result in irreversible changes leading to loss of periodontal support.

- Contact time with metallic restoration is 0.4 seconds to prevent pulpal damage.

\section{Post-operative instructions [5]}

- Smoking, alcohol, high spice level food should be avoided following surgery.
- Avoid forceful brushing in and around surgical site for few days post-surgery.

- Analgesics can be used to provide relief from post operative discomfort.

- Application of ice packs to the surgical site helps in reduction of inflammation.

- $\quad$ Doctor should be informed if anything goes uneventful.

Literature on Electrosurgery in Dentistry

- Series of cases has been documented on the use of ES in frenectomy techniques such as Miller's technique, V-Y plasty and Z plasty [6].

- Verco has published a case report on use of electrosurgery for the management of tongue tie in a 8 years old child [7].

- Kurtzman has documented a case report on usage of bipolar ES unit for gingivoplasty in passive eruption [8].

- Series of cases has been reported by Kusum on the use of monopolar ES unit in gingivectomy and gingivoplasty around fractured tooth, carious lesion [9].

- Vital pulp treatment with bipolar ES unit electrocoagulation after exposure of pulp intentionally [10].

- $\quad$ Pope., et al. found that healing after electrosurgery persisted for a long time than with traditional methods [11].

Highlights [12]

- Bloodless field provides clear view.

- Tissue separation is neat and clean.

- $\quad$ Pressure less and precise.

- Possible soft tissue planning.

- Post-operative discomfort is minimal.

- $\quad$ Scarring is minimal.

- $\quad$ Can be used in poorly accessible sites.

- $\quad$ Reduced chair time.

Drawbacks [12]

- Cannot be used near inflammable gases.

- $\quad$ Tissue burning odor is unacceptable by some patients.

- $\quad$ Cost expensive. 


\section{Conclusion}

It should be noted that ES can never be used to replace the conventional or manual methods. Use of ES unit requires an understanding of biological tissues and physical effects of electric current on tissues. Use of electrosurgery in dental field is considered as ideal for cutting and coagulation.

\section{Bibliography}

1. Osman FS. "Dental electrosurgery: General precautions". Journal of the Canadian Dental Association (1982): 642.

2. Pearce JA. "Electrosurgery". New York: Wiley Medical (1986).

3. Caffee HH and Ward D. "Bipolar coagulation in microvascular surgery”. Plastic and Reconstructive Surgery (1986): 374-377.

4. Yalamanchili., et al. "Electrosurgical applications in Dentistry". Scholars Journal of Applied Medical Sciences (2013): 530-534.

5. Stevens V., et al. "Quantitative analysis of heat generated during electrosurgery". Journal of Dental Research (1981): 432.

6. Devishree., et al. "Frenectomy: A Review with the Reports of Surgical Techniques". Journal of Clinical and Diagnostic Research (2012): 1587-1592.

7. Verco PJW. "Case report and clinical technique: argon beam electrosurgery for tongue ties and maxillary frenectomies in infants and children". European Archives of Paediatric Dentistry 8.1 (2007).

8. Gregori M., et al. "Bipolar Electrosurgery: Gingival Modification in Passive Eruption Cases". Dentistry Today (2008): 112114.

9. Kusum Bashetty., et al. "Electrosurgery in aesthetic and restorative dentistry: A literature review and case reports". Journal of Conservative Dentistry (2009): 139-144.

10. Livaditis GJ. "Vital pulp therapy with bipolar electrocoagulation after intentional pulp exposure of fixed prosthodontic abutments: a clinical report". Journal of Prosthetic Dentistry (2006): 400-406.

11. Pope JW., et al. "Effects of electrosurgery on wound healing in dogs". Periodontics (1968): 30-37.

12. Shuman IE. "Bipolar Versus Monopolar Electrosurgery: Clinical Applications". Dentistry Today (2001): 74-81.

\section{Assets from publication with us}

- Prompt Acknowledgement after receiving the article

- Thorough Double blinded peer review

- Rapid Publication

- Issue of Publication Certificate

- High visibility of your Published work

Website: www.actascientific.com/

Submit Article: www.actascientific.com/submission.php

Email us: editor@actascientific.com

Contact us: +919182824667 